\title{
SLOVENSKA IMENA BITIJ IN ZEMLJEPISNA IMENA V TURISTIČNIH VODNIKIH IN VIRIH INFORMATIVNE NARAVE, PREVEDENIH V FRANCOŠČINO'
}

\section{UVOD}

Namen pričujočega pisanja je ugotoviti, kako se kaže prevajalska praksa v besedilih, namenjenih francosko govorečim turistom, oziroma, kako so prevedena imena bitij in zemljepisna imena $\mathrm{v}$ brošurah, ki so tujim obiskovalcem na voljo $\mathrm{v}$ turističnih pisarnah ali na spletni strani Slovenske turistične organizacije. Pod drobnogled smo vzeli brošuri Faits sur la Slovénie, ki ju je izdala Vlada Republike Slovenija, Pisarna za odnose z javnostjo in mediji v letih 2001 in 2006, ter brošuri Association des villes historiques de Slovénie in La randonnée pédestre en Slovénie, ki ju je izdala Slovenska turistična organizacija v letih 2005 in 2010.

Prevodi analiziranih besedil so plod sodelovanj slovenskih in francoskih prevajalcev (brošuri Vlade RS) ali slovenskih prevajalskih agencij (brošuri STO). Besedila so pragmatične narave. Njihov cilj je bralcu približati vsebino, upoštevati njegove konkretne potrebe, podati lokalni in bajeslovni kolorit, ...

Vprašanja, ki se nam ob tem postavljajo, so naslednja:

- v kolikšni meri se prevajalci odločajo za ohranjanje izvirnega slovenskega poimenovanja (prenos),

- kdaj se odločijo za pojasnjevalni dodatek (eksplicitacija) in

- kdaj (če sploh) se odločijo za prilagajanje ali prevajanje imena (naturalizacija, ustreznice).

Ob iskanju odgovorov na omenjena vprašanja komentiramo pomensko in slovnično jasnost prevajalske rešitve, ne $\mathrm{z}$ namenom vzpostavljanja dihotomije prav/narobe, marveč zato, da nekako ocenimo jasnost prevoda posameznega imena ali besedne zveze ter zvestobo izvirnemu poimenovanju.

Ker se bo tujec »na terenu « srečal z izvirnimi poimenovanji, je pričakovati, da bodo slovenska lastna imena $\mathrm{v}$ brošurah ohranjena in na neki način tudi pojasnjena. Predvidevamo, da bodo pojasnjena zlasti pomensko očitno motivirana imena in kulturno/geografsko specifična poimenovanja. Pri tem seveda izhajamo iz predpostavke, da večina osebnih imen ni kulturno specifična in ne potrebuje dodatnega pojasnjevanja ter da so zemljepisna lastna imena pomensko motivira-

1 Pričujoči prispevek je nastajal vzporedno $\mathrm{z}$ magistrskim delom Lastno ime in prevajanje na podiplomskem programu francoskega jezikoslovja. Za akribijo se zahvaljujemo doc. dr. Gregorju Perku. 
na, četudi je motivacija dandanes lahko (delno ali popolnoma) zabrisana, kar z vidika informativnosti ali zapomnljivosti terja dodatno pojasnjevanje.

Pri pričujočem pregledu primerov iz prakse se opiramo na delitev lastnih imen po Slovenskem pravopisu, ki deli lastna imena v tri skupine: imena bitij, stvarna imena ter zemljepisna imena. V prispevku bomo na kratko pogledali, kako so prevedena imena prvih dveh skupin, podrobneje pa si bomo ogledali tretjo skupino imen, ki je zaradi narave korpusa pričakovano najbolj obširna.

\section{LASTNO IME}

Lastna imena so poimenovanja posameznih bitij (tudi živali), zemljepisnih in stvarnih danosti (npr. imena krajev, delov zemeljskega površja, nebesnih teles, ustanov, delovnih organizacij in podjetij, umetnostnih del, ipd.) Med imena bitij uvrščamo osebna imena, verska in bajeslovna imena, alegorične poosebitve, imena prebivalcev in živalska imena. Med zemljepisna imena uvrščamo naselbinska imena (imena mest, vasi, trgov, zaselkov) in nenaselbinska imena (vsa druga imena). Stvarna imena zaznamujejo posamezne knjige, besedila, kipe in druga umetnostna dela, organizacije, ustanove, podjetja, lokale, nekatera vozila, industrijske znamke, ipd.

\subsection{Lastno ime in prevajanje}

Newmark (1988) je v svojem delu podal smernice za prevajanje lastnih imen, ki jih bomo na kratko povzeli v nadaljevanju.

Osebna imena $v$ ciljni jezik običajno prenesemo. S tem ohranimo oznako njihove narodne pripadnosti. Izjemoma se osebna imena prevedejo: predvsem imena vladarjev, papežev, svetnikov ali imena v leposlovnih delih, ki vsebujejo konotacije. Druga imena, večinoma gre za imena iz klasične književnosti, v ciljnem jeziku naturaliziramo oziroma po zapisu prilagodimo pravilom ciljnega jezika (npr. lat. Horatius $\rightarrow$ slov. Horacij). Imena pri katerih je pomembna tako narodna pripadnost kot njihova konotacija, lahko prevedemo in naturaliziramo (Nabatov, Alarmov).

Stvarna imena, vključno z imeni blagovnih znamk, običajno v ciljni jezik prenesemo.

Zemljepisnim imenom poiščemo ustreznico v atlasu ali na zemljevidu. Če te ni, imena $v$ naslovih prenesemo. Če se krajevna imena pojavljajo v drugačnem sobesedilu, denimo v turističnih brošurah, potem jih (vsaj delno) prevedemo.

Glede na opisane smernice pričakujemo, da bomo pri analizi lastnih imen v turističnih besedilih naleteli v glavnem na naslednje prevajalske postopke:

- prenos (transkripcija, sposojenka; gre za prenos besede iz izvirnega jezika v ciljni jezik),

- opisna ustreznica (gre za opisno analizo nekega izraza),

- priznani prevod (uporaba uradnega ali splošno sprejetega prevoda),

- direktni prevod (dobesedni prevod kolokacij, imen organizacij, elementov zloženk, fraz; kalkiranje). Hkrati pričakujemo v prevodih tudi pojasnjevalne opombe. 


\section{LASTNOIMENSKA ANALIZA SLOVENSKIH TURISTIČNIH BESEDIL SLOVENSKE TURISTIČNE ORGANIZACIJE, PREVEDENIH V FRANCOŠČINO}

\subsection{Imena bitij}

\section{Osebna imena}

Osebna imena pri prevajanju običajno ostajajo nespremenjena. Prevajalski postopek se imenuje prenos. Gre za popolno odsotnost prevajanja, prevajalec namreč besedo iz izvirnega jezika prenese v ciljni jezik. Najpogosteje se pojavi izvirni oziroma citatni zapis:

arhitekt Jože Plečnik $\rightarrow$ l'architecte Jože Plečnik,

kipar Marko Pogačnik $\rightarrow$ le sculpteur Marko Pogačnik².

\section{Veroslovna in bajeslovna imena}

Pri veroslovnih in bajeslovnih imenih $\mathrm{v}$ prevodih gre $\mathrm{v}$ glavnem za iskanje ustreznice:

sveti Lenart $\rightarrow$ St. Lenart,

sveti Frančišek $\rightarrow$ St. François,

sveti Jakob $\rightarrow$ St. Jacob,

sveti Krištof $\rightarrow$ Saint Christophe,

Prevajalci so občnoimensko sestavino prevedli in v glavnem skrajšali v St., lastnemu imenu pa so poiskali ustreznico v ciljnem jeziku. Naslednji primer se od navedenih razlikuje po nekako nedokončanem postopku prevajanja:

Janez Krstnik $\rightarrow$ Jean Krstnik.

Prevajalec je prvemu delu imena poiskal ustreznico, drugi del pa je zapisal citatno. Delnim prevodom se je v prevajalski praksi bolje izogibati: ali prevedemo celo ime ali pa ohranimo citatni zapis. V tem primeru ni nobenega dvoma, kako se glasi francoski prevod:

Janez Krstnik $\rightarrow$ Jean-Baptiste.

$\mathrm{V}$ naslednjem primeru je prevajalec $\mathrm{v}$ besedilu ohranil tradicionalno slovensko poimenovanje (občnoimensko sestavino je prevedel), hkrati pa je francoskemu bralcu v oklepaju ponudil tudi francosko poimenovanje. Tako je bralec v zadostni meri poučen o imenu oz. njegovi francoski inačici, da ob naslednjih pojavitvah tovrstna pojasnila niso več potrebna in lahko prevajalec ohranja izvirno poimenovanje tudi v prevodu.

kralj Matjaž $\rightarrow$ le roi Matjaž (Mathias).

Pri imenih svetnic se pojavlja drugačen zapis: pridevnik »sveti« pred imenom je bodisi zapisan v neskrajšani obliki, bodisi v skrajšani ženski obliki brez pike. Videti je tudi, da se v primeru neskrajšanega zapisa med pridevnik in samostalnik vrine vezaj:

\footnotetext{
2 Le izjemoma naletimo na primer, ko francoski prevajalec ime slovenskega avtorja $\mathrm{z}$ naturalizacijo približa francoskemu bralcu. V tem primeru gre za prilagoditev šumnikov: Žarko Petan $\rightarrow$ Zarko Petan. Poudarjamo, da gre za edinstven primer, ki je rezultat dela francoskega, ne slovenskega prevajalca. Primer navajamo le kot ilustracijo, saj ga nismo našli v primarnih virih, pač pa v leposlovnem delu.
} 
Sveta Marija $\rightarrow$ Sainte-Marie,

Sveta Katarina $\rightarrow$ Ste Catherine.

\section{Imena prebivalcev}

Slovenci $\rightarrow$ les Slovènes.

Pri imenih prebivalcev nismo zaznali nobenih posebnosti.

\section{4. Živalska imena}

lipicanci $\rightarrow$ les Lipizzans, les lipizzans.

Prevajalec se je verjetno odločil za pisanje $z$ veliko začetnico zaradi analogije $z$ imenom Lipica. Ce bi se odločil za inačico s predlogom »de«, potem bi po zgledu »soška postrv« $\rightarrow$ »la truite de Soča « verjetno zapisal:

lipicanec $\rightarrow$ le cheval de Lipica.

\subsection{Zemljepisna imena}

\section{Kraji, deli krajev, ulice, trgi, ceste}

a) Imen krajev običajno ne prevajamo

Ljubljana $\rightarrow$ Ljubljana; naleteli smo tudi na dokaj »svež« primer: Lubjana ${ }^{3}$.

Sicer pa:

Koper $\rightarrow$ Koper,

Maribor $\rightarrow$ Maribor;

ali s pojasnjevalnim dodatkom »la ville de«:

Ptuj $\rightarrow$ la ville de Ptuj.

Če bi poimenovanje »la ville de Ptuj« prevedli nazaj v slovenščino, bi se dobesedni prevod po analogiji s poimenovanjem »le lac de Cerknica« glasil »Ptujsko mesto .

Včasih prevajalec presodi, da je ime zanimivo tudi s pomenskega vidika in se odloči za pojasnjevalni prevod imena, kar označi z navednicami:

Portorož $\rightarrow$ l'ancien »Port aux roses «.

V tem primeru gre za opisno ustreznico. Osnova tega prevoda je italijansko poimenovanje Portoroža, Portorose.

b) Imena ulic

Občnoimensko sestavino imena so prevajalci prevedli, lastnoimensko sestavino pa pustili nespremenjeno. Pri tem se zamenja tudi besedni red, saj občnoimenska sestavina $\mathrm{v}$ francoščini stoji pred lastnoimensko sestavino:

Čopova ulica $\rightarrow$ la rue Čopova,

Cankarjeva ulica $\rightarrow$ le rue Cankarjeva,

Študentovska ulica $\rightarrow$ la rue Študentovska,

Erjavčeva cesta $\rightarrow$ la rue Erjavčeva.

c) Imena trgov in parkov

Imena trgov in parkov se prevaja: 
Trg republike $\rightarrow$ la place de la République.

Zanimivo pri tem je, da je v slovenščini občnoimenska sestavina »trg« del lastnega imena, saj je zapisana $z$ veliko začetnico. $V$ francoščini se njen status spremeni, saj je zapisana $z$ malo začetnico. Lastnoimenska sestavina imena ostane torej le »République«. Če bi hoteli ohraniti izvirno sestavo imena, bi potemtakem raje zapisali: »la Place de la République«.

$\mathrm{V}$ prevodu lahko ohranimo slovenski zapis, ki mu dodamo pojasnjevalno občnoimensko sestavino:

Gornji trg $\rightarrow$ la place Gornji trg,

Levstikov trg $\rightarrow$ la place Levstikov trg,

park Zvezda $\rightarrow$ le parc Zvezda,

Prešernov trg $\rightarrow$ la place Prešeren.

Če bi zadnje francosko poimenovanje prevedli nazaj v slovenščino, bi bržkone dobili »trg Prešeren«, kar je oddaljitev od izvirnika. Izvirniku bližji prevod bi se potemtakem glasil: Prešernov trg $\rightarrow$ la place de Prešeren (glej zgoraj »la place de la République«), verjetno pa pa ne bi bilo nič narobe z zvezo »la place Prešernov $\operatorname{trg} \ll$.

\section{Države, enote zveznih držav, pokrajine}

Poglejmo si, kako so prevajalci slovenili nekaj državnih poimenovanj iz naše (pol)pretekle zgodovine:

Slovenija $\rightarrow$ la Slovénie,

Kraljevina SHS $\rightarrow$ l'Etat des Slovènes, des Croates et des Serbes,

Federativna Ljudska Republika Jugoslavija $\rightarrow$ la République Fédérale et Populaire de Yougoslavie,

Socialistična Federativna Republika Jugoslavija $\rightarrow$ la République Fédérale Socialiste de Yougoslavie,

Socialistična Republika Slovenija $\rightarrow$ la République socialiste de Slovénie.

Pomensko šibkejši prevod opazimo pri prevodu izraza »Kraljevina SHS «, kjer se v francoski različici »l'Etat des Slovènes, des Croates et des Serbes « izgubi podatek, da gre za kraljevino, »royaume«, ne zgolj državo. Po vsej verjetnosti gre v naštetih primerih za sprejete uradne prevode.

Več možnih različic opazimo pri prevodih imen pokrajin. Prevajalci običajno uporabljajo tri strategije:

- ime pokrajine pustijo v izvirni obliki in pred ime po analogiji s spolom v izhodiščnem jeziku postavijo ustrezni določni člen,

- ime pustijo v izvirniku, spredaj postavijo ustrezni določni člen ter v oklepaju navedejo polatinjeno keltsko poimenovanje,

- uporabijo le staro polatinjeno keltsko poimenovanje.

Poglejmo si to na primerih:

Koroška $\rightarrow$ la Koroška, la Koroška (Carinthie), la Carinthie;

Štajerska $\rightarrow$ la Štajerska, la Styrie;

Dolenjska $\rightarrow$ la Dolenjska, la Basse-Carniole, la région de Dolenjska;

Notranjska $\rightarrow$ la Carniole intérieure;

Gorenjska $\rightarrow$ la Haute-Carniole. 
Kjer polatinjeno keltsko poimenovanje ne obstaja, se lahko ohrani citatni zapis z ustreznim določnim členom oziroma se pred ime pokrajine doda pojasnjevalni dodatek »la région de ${ }^{4}$.

Bela Krajina $\rightarrow$ la Bela Krajina, Bela Krajina, la région de Bela Krajina;

Prekmurje $\rightarrow$ le Prekmurje;

Primorje $\rightarrow$ le Primorje, la Primorska (littoral), le Primorje (Littoral), le Littoral, le littoral (Primorska);

Izmed navedenih primerov izstopata dva: »Bela Krajina« brez člena ter več različnih možnosti prevodov za Primorje. $Z$ jezikovnega stališča so zanimivi primeri, ko se prevajalci odločijo za spremembo v pisanju velike/male začetnice, in $\mathrm{s}$ tem spremembe statusa imena.

Drugi primeri, ki smo jih našli, so naslednji:

Kras $\rightarrow$ le Kras, le Karst, le karst;

Pohorje $\rightarrow$ le Pohorje;

Panonska nižina $\rightarrow$ la plaine Pannonienne, la plaine pannonienne;

Pomurje $\rightarrow$ le Pomurje, la région de Pomurje;

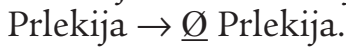

Beseda »kras« je mednarodno uveljavljena beseda za kraško pokrajino s tipičnimi kraškimi pojavi, zato po Klinarjevem mnenju (1994: 14) ni nobenega zadrž$\mathrm{ka}$, da se ne bi uporabljalo slovensko poimenovanje. Po analogiji $\mathrm{z}$ angleškim »the Kras « (z določnim členom in veliko začetnico) bi Klinar za francoski jezik bržkone predlagal inačico »le Kras« namesto nemške vzporednice »Karst«. Podobno tudi ni razloga, da bi »plaine pannonienne k kot geografsko poimenovanje za del slovenskega ozemlja pisali z malo začetnico. Vsaj ob prvem poimenovanju bi kazalo uporabiti pojasnjevalni dodatek skupaj z izvirnim slovenskim poimenovanjem, kjer bi v oklepaju ali navednicah zapisali tudi prevod: »la plaine Panonska nižina (la Plaine Pannonienne)«. Tako bi lahko v preostalem delu besedila besedno zvezo ohranili v izvirnem zapisu.

Imena manjših pokrajin se običajno prevedejo s pojasnjevalno zvezo »la région de « pred lastnoimensko sestavino. $V$ dveh primerih spodaj iz te pojasnjevalne zveze izgine predlog »de $\ll^{5}$. Ob tem doživi spremembo tudi lastnoimenska sestavina: pokrajina »Kočevsko« postane pokrajina »Kočevje«, ki je med slovenskimi geografskimi poimenovanji ne zasledimo, v nasprotju s pokrajino »Dolenjska«. Ob spremembi izvirnega poimenovanja »Dolenjsko« $\mathrm{v} »$ Dolenjska« se bo pomenska razlika domačemu govorcu zdela minimalna, jezikoslovec pa bo verjetno pripomnil, da tudi nepotrebna.

Banovci $\rightarrow$ la région de Banovci,

Solčavsko $\rightarrow$ la région de Solčavsko,

Kočevsko $\rightarrow$ la région Kočevje,

Dolenjsko $\rightarrow$ la région Dolenjska,

\footnotetext{
4 S. Klinar o polatinjenih keltskih imenih zapiše: »Polatinjena keltska imena so primerna za znastveni slog, medtem ko se je v leposlovju in vsakdanjem govoru bolje zatekati k slovenskim imenom, zlasti kadar gre za manjše enote.« (1994: 13).

Gre za predlog, ki nima pomena, za t. i. »préposition vide«, ki pa je v francoščini zelo pogosto uporabljen. V tem primeru označuje prilastek. Uporablja se za imena mest in gora, redkeje za imena rek. (Mauger, 1968: 43)
} 
Goriško $\rightarrow$ la Goriška,

$\mathrm{Brda} \rightarrow$ la région de Brda.

Poimenovanja kot so »Solčavsko, Kočevsko, Dolenjsko, Goriško ipd « so za Klinarja preohlapna za prevajanje. V prevodu se naravneje glasijo s pojasnjevalnim dodatkom (1994: 14). S tega vidika je poimenovanje »la région de Goriško« bolj priporočljivo in bolj jasno kot poimenovanje »la Goriška«.

\section{Tekoče vode, morski tokovi, prekopi, jezera, morja, oceani}

\section{a) Imena rek}

Pred ime reke postavimo določni člen »la«:

Sava $\rightarrow$ la Sava in la Save,

Sava Bohinjka $\rightarrow$ la Sava Bohinjka,

Soča $\rightarrow$ la Soča,

Vipava $\rightarrow$ la Vipava,

Kolpa $\rightarrow$ la Kolpa,

$\mathrm{Krka} \rightarrow$ la Krka, toda:

Jezernica $\rightarrow$ la Jezernica,

Donava $\rightarrow$ le Danube.

Sprememba spola $v$ tem primeru ni nenavadna, saj gre za splošno pravilo t. i. večjih rek, ki so po analogiji z občnoimensko sestavino »fleuve « moškega spola.

Pred ime reke lahko dodamo tudi pojasnjevalno občnoimensko sestavino »la rivière«:

Reka $\rightarrow$ la rivière Reka,

Savinja $\rightarrow$ la rivière Savinja,

Mura $\rightarrow$ la rivière Mura, la Mura,

Ljubljanica $\rightarrow$ la rivière Ljubljanica, la Ljubljanica,

Soča $\rightarrow$ la rivière Soča, la Soča,

toda:

Kolpa $\rightarrow$ la rivière Kupa, kjer iskreno upamo, da je nastalo poimenovanje posledica tipkarske napake...

\section{b) Imena slapov}

Imena slapov $\mathrm{v}$ prevodu nekako terjajo občnoimensko sestavino »la chute, la cascade, la chute d'eau «. V primeru, da te ne bi dodali, bi tujec bržkone pomislil, da je govora o reki, ne o slapu. Primerjajmo: »la Savica« (reka) in »la chute Savica« (slap).

slap Savica $\rightarrow$ la chute Savica, la chute d'eau Savica, la cascade de la Savica;

Če bi zadnje ime prevedli nazaj v slovenščino, bi bržkone dobili »slap Savice« ali »slap reke Savica«.

slap Šum na Radovni $\rightarrow$ la chute Šum na Radovni,

slap Rinka $\rightarrow$ la chute Rinka, slap Kozjak $\rightarrow$ la chute Kozjak,

$\overline{6}$ Ime Savica nosita slap in potok, ki pade v slap. 
slap Šumik $\rightarrow$ la chute d'eau de Šumik ${ }^{7}$,

slap Mostnica $\rightarrow$ la chute de la Mostnica; struktura »de la« da vedeti, da gre za slap reke Mostnice (»la chute de la rivière Mostnica«),

slap Martuljek $\rightarrow$ la cascade de Martuljek.

Če bi ime »la cascade de Martuljek « prevedli nazaj v slovenščino, bi dobili »Martuljški slap«, torej tukaj ne bi bilo prav nič narobe s prevodom »la cascade Martuljek«. Slap je dobil ime po potoku »Martuljek«. Enako se imenuje tudi gozd, skozi katerega teče omenjeni potok. Imeni slapov se uradno glasita »Zgornji« in »Spodnji Martuljški/Martuljkov slap«. Prevajalcu se morda ob takih primerih poraja vprašanje, ali naj pri prevodu upošteva izvirno slovensko besedilo, ali pa uradno poimenovanje. Ce smo natančni in dlakocepski, »slap Martuljek « namreč ne obstaja. Glede na dejstvo, da sta slapova poimenovana po potoku (gozdu), ocenjujemo, da je prevod s predlogom »de« boljši, saj je pomensko bližji izvirniku.

Našli smo tudi inačico imena brez člena:

Čedca $\rightarrow$ Čedca.

Kasnejši zapis je »la chute d'eau Čedca«.

\section{c) Imena korit, sotesk, ipd.}

kanjon Mostnice $\rightarrow$ le canyon Mostnica

Podobno kot »slap Martuljek« tudi »kanjon Mostnica« ne obstaja. Viri navajajo »kanjon Mostnice«, zato bi bil ustreznejši prevod »le canyon de la Mostnica«.

korita Mostnice $\rightarrow$ les gorges Korita Mostnice

$V$ tem primeru opazimo spremembo lastnega imena: slovenska občnoimenska sestavina besedne zveze postane $\mathrm{v}$ francoščini del lastnega imena, zapisana $z$ veliko začetnico. Ocenjujemo, da je prevod zelo jasen, saj je prevajalec ohranil izvirno slovensko poimenovanje naravnega pojava, ki mu je dodal pojasnjevalno občnoimensko sestavino.

Blejski vintgar $\rightarrow$ la gorge de Bled, les gorges Vintgar, le Vintgar.

Pomensko prvi prevod ni neustrezen, vendar bo tujec, ki bo raziskoval Bled, prej naletel na zapis »Blejski vintgar«, kot pa na zapis »la gorge de Bled «, če sploh. Zatorej bi bilo v luči jasnosti in turistom prijaznega besedila primerneje, če bi se prevod glasil »la gorge Blejski vintgar«. Drugi prevod je mešanica prvega in tretjega prevoda, ohranil je občnoimensko sestavino »vintgar«, ki jo je spremenil v lastno ime in zapisal z veliko začetnico, pred njo pa postavil pojasnjevalno občnoimensko sestavino. Ocenjujemo, da je sprememba v številu nepotrebna, saj tudi slovenski viri navajajo, da gre za sotesko, ne soteske. Predvsem zaradi besedila, ki govori o Bledu in njegovi okolici, sklepamo, da je prevajalec (ali avtor) namenoma izpustil pridevnik »Blejski«, saj naj bi bila lokacija iz besedila nekako očitna. Tretji prevod je najkrajši, tako da imamo na opisanih primerih priložnost opazovati, kako se poimenovanje naravnega pojava $v$ besedilu razvija oziroma poenostavlja, kar je z besediloslovnega stališča ekonomičnosti naraven pojav: »la gorge Blejski

\footnotetext{
7 »Šumik« je ime pragozda, kjer teče reka Lobnica, ki pade v slap Veliki Šumik in kasneje še Mali Šumik. Za opis prevajalske zagate glej primer »slap Martuljek«.
} 
vintgar«(*predlagani prevod) $\rightarrow$ »les gorges Vintgar« (nepotrebna množina) $\rightarrow$ le Vintgar«.

Mala korita Soče $\rightarrow$ la petit (zapisano brez ženske končnice -e) gorge (Mala korita) de la rivière Soča,

Tolminska korita $\rightarrow$ les gorges de Tolmin, la gorge de la Tolminska korita

Medtem ko se nam prvi prevod ne zdi sporen (razen neupoštevanja skladenjskega ujemanja), bi lahko drugemu prevodu očitali dvoje: najprej to, da so korita $\mathrm{v}$ množini in ne v ednini, kot je sklepati iz prevoda. A to bi bil pravzaprav dlakocepski očitek, ki bo nejezikoslovcu popolnoma odveč. Drugi očitek bi bil, da »la Tolminska korita« ne obstajajo..., kvečjemu »la gorge Tolminska korita«.

soteska Pasice $\rightarrow$ la gorge de Pasica

Besedna zveza »de Pasica« da misliti, da je Pasica ime kraja (glej zgoraj »de Tolmin«), kar je zavajajoče. Pasica je namreč ime rečice, ki teče skozi sotesko, zatorej rajši predlagamo »la gorge de la Pasica«.

\section{c) Imena jezer}

Ime kraja postane prilastek občnoimenske sestavine:

Cerkniško j. $\rightarrow$ de Cerknica,

Bohinjsko j. $\rightarrow$ de Bohinj,

Krnsko j. $\rightarrow$ de Krn.

Naštejmo še nekaj imen:

Cerkniško jezero $\rightarrow$ le lac de Cerknica, le lac de Cerkno,

Bohinjsko jezero $\rightarrow$ le lac de Bohinj,

Krnsko jezero $\rightarrow$ le lac de Krn,

Blejsko jezero $\rightarrow$ le lac de Bled,

Lovrenška jezera $\rightarrow$ les lacs de Lovrenc,

Triglavska jezera $\rightarrow$ les lacs du Triglav,

Tu bi bralec zaradi člena »du« verjetno sklepal, da ne gre za ime kraja, sicer bi se ime glasilo »* le lac de Triglav«, marveč za ime gore.

Planšarsko jezero $\rightarrow$ le lac de Planšar,

jezero Jasna $\rightarrow$ le lac de Jasna;

Če je v zgornjih primerih besedna zveza sestavljena iz predloga »de« in imena kraja, kakšna je potem vloga besed »Planšar« in »Jasna«? Domačemu govorcu je očitno, da ne gre za krajevni imeni. Morda bi potemtakem veljalo pojasniti vsaj prvo poimenovanje (»Planšar«), kjer je pomenska motivacija še nekako očitna, pri drugem pa dodati, da gre pri »Jasni«za ime lokala. V francoščini bi se ime seveda uporabilo brez člena, naraven prevod bi se bržkone glasil »Chez Jasna«.

Prevajalci se odločajo tudi za ohranitev slovenskega poimenovanja, pred katerega dodajo občnoimensko sestavino:

Ribniško jezero $\rightarrow$ le lac Ribniško jezero,

Črno jezero $\rightarrow$ le lac Črno jezero,

Divje jezero $\rightarrow$ le lac Divje jezero.

Naslednji prevod avtorju ni najbolj uspel:

Lovrenška jezera $\rightarrow$ ceux (»les lacs de«, op. avtorica) de Lovrenško jezero

Pri tem poimenovanju bi tujec sicer razumel, da je jezer več, a bi verjetno sklepal tudi, da je Lovrenško jezero ime kraja. Verjetno bi bila razumljivejša prevoda 
»les lacs Lovrenška jezera« ali »les lacs de Lovrenc«. Podobna pripomba bi veljala za izraz »les lacs de Lovrenška jezera«: predlog »de« se verjetno v prevod vrine po analogiji z izrazi »de Cerkno, de Krn, ipd.«, kjer za predlogom stoji ime kraja. Potemtakem bi lahko tujec sklepal, da je »Lovrenška jezera« ime kraja, ki bi ga neuspešno skušal najti na zemljevidu.

\section{d) Imena morij}

Jadransko morje $\rightarrow$ la mer Adriatique, l'Adriatique, la Mer Adriatique,

Sredozemsko morje $\rightarrow$ la Méditerrannéen, la Méditerranée.

Pri imenih morij gre za ustaljene prevode, ki so v rabi že dolgo časa. Prevodno rešitev bi komentirali le $\mathrm{z}$ jezikoslovnega gledišča, ko prevajalec izbira pisanje $\mathrm{z}$ veliko ali malo začetnico: »mer/Mer«, kjer (ne)hote izbira med lastnoimenskim in občnoimenskim poimenovanjem. Ob tem pripomnimo, da je v slovenščini jedro besedne zveze občno ime, zapisano $z$ malo začetnico. Kot neuspel prevod lahko ocenimo prevod »la Méditerrannéen «, ki je po vsej verjetnosti skrajšana oblika poimenovanja »la mer Méditerranéenne«.

\section{Vzpetine, doline, nižine, katastrske enote in njihove skupine, gozdovi, puščave, jame}

a) Imena sedel

Korensko sedlo $\rightarrow$ le col de Koren, le col Korensko sedlo, vendar hkrati

Jezerski vrh, Krvavi Potok, Dolič brez pojasnjevalnega dodatka;

Vršič $\rightarrow$ le col du Vršič, kjer je razumeti, da je »Vršič« ime vrha, gore. Pomensko motivacijo bi lahko pojasnili na dva načina. $V$ osnovi imena prelaza bi se lahko skrival dvatisočak Suhi vrh nad Vršičem, čigar ime se je po metonimiji preneslo na sam prelaz. Drugo (bolj verjetno) pojasnilo je, da je v osnovi imena prelaza ime lažje dostopnega vrha nad Poštarsko kočo, Vršiča (Vršič vrh). Kakorkoli, »Vršič« je danes (tudi) ime prelaza, torej bi bil ustreznejši prevod »le col Vršič«.

Podobno:

Prag $\rightarrow$ le Prag,

Kamniško sedlo $\rightarrow$ le col de Kamnik,

sedlo Komisija $\rightarrow$ le col de Komisija.

\section{b) Imena gozdov in planot}

Trnovski gozd $\rightarrow$ la forêt de Trnovo, la forêt Trnovski gozd;

Trnovsko-Banjška planota $\rightarrow$ Trnovsko-Banjška planota plateau.

$\mathrm{V}$ zadnjem primeru se je prevajalec odločil za $\mathrm{v}$ francoščini neobičajen besedni red, kjer je jedro besedne zveze postavil na konec, ne na začetek besedne zveze. Morda bi zaradi jasnosti rajši predlagali zapis z navednicami: plateau »TrnovskoBanjška planota«.

Imena lahko ostanejo v prevedenem besedilu tudi povsem nespremenjena in brez pojasnjevalnih dodatkov: Banjščice, Trnovski Gozd, Javorniki, Bloška planota, Kočevski Rog. 


\section{c) Imena bribovij}

Skofjeloško hribovje $\rightarrow$ les montagnes de Škofja Loka,

Idrijsko in Cerkljansko hribovje $\rightarrow$ les montagnes d'Idrija et de Cerkljansko,

Posavsko hribovje $\rightarrow$ les montagnes de Posavje, les Collines de Posavje.

$\mathrm{V}$ zadnjem primeru je prevajalec občnoimensko sestavino spremenil $\mathrm{v}$ lastnoimensko kljub temu, da $\mathrm{v}$ slovenščini tega statusa nima.

Vipavsko hribovje $\rightarrow$ les collines de Vipava,

Kumljansko $\rightarrow$ les montagnes Kumljansko.

Vendar tudi:

(...) dans les regions montagneuses slovènes de moyenne altitude où vous disposez de nombreux sentiers dans l'Idrijsko, Cerkljansko, Škofja Loka, Polhograjsko, Posavje, Pohorje ... (...).

Primerjajmo krajšanje določnega člena v »l'Idrijsko« in »le Uršlja gora«; ter »1'Idrijsko (verjetno je mišljeno »hribovje«)《 in »Škofja Loka (hribovje?, op. a.)《 ali »Pohorje (hribovje?, op. a.).

\section{c) Imena gorskib verig}

Pred imeni gorskih verig dodamo določni člen v množini, ime dobi množinsko končnico, občnoimensko sestavino pa zapišemo z veliko začetnico:

Alpe $\rightarrow$ les Alpes,

Julijske alpe $\rightarrow$ les Alpes juliennes,

kjer sestavini imena pridobita obraten status: občnoimenska sestavina postane lastnoimenska in obratno.

Toda:

Karavanke $\rightarrow$ les Karavanke $\underline{\emptyset}^{8}$, brez množinskega obrazila (primerjaj s prevodom »le Škarje« ali »les Ciprnik«), ter:

Kamniško-Savinjske alpe $\rightarrow$ les Alpes de Kamnik-Savinja, s predlogom »de«. Sprašujemo se, ali ne bi bil bolj jasen prevod: »les Alpes de la région de Kamnik-Savinja«. Tuji govorec brez dodatnega brskanja po literaturi iz imena verjetno ne bi razbral, da gre pri imenu Kamnik-Savinja za ime pokrajine, marveč bi po analogiji bržkone razmišljal, da gre za ime kraja, kar je sicer deloma res.

Verjetno lahko v isto skupino uvrstimo ime skupine vrhov v Kamniško-Savinjskih Alpah, Grintovcev: »le Grintovci«. Prevod se pomensko oddalji od izvirnika, saj zaradi uporabljene ednine ne navaja na misel, da ne gre za en sam vrh, marveč skupino vrhov.

\section{d) Imena vrhov}

Pred imeni vrhov dodamo določni člen $v$ ednini, upoštevajoč spol samostalnika v izvirniku:

Triglav $\rightarrow$ le Triglav,

Škrlatica $\rightarrow$ la Skrlatica,

Grintovec $\rightarrow$ le Grintovec,

8 Ime spominja na nemško poimenovanje, Karawanken. 
Kanjavec $\rightarrow$ le Kanjavec,

Nanos $\rightarrow$ le Nanos,

Snežnik $\rightarrow$ le Snežnik,

Pršivec $\rightarrow$ le Pršivec,

Viševnik $\rightarrow$ le Viševnik,

Črna prst $\rightarrow$ le Črna prst,

Kanin $\rightarrow$ le Kanin,

Prestreljenik $\rightarrow$ le Prestreljenik,

Vogel $\rightarrow$ le Vogel, le sommet Vogel,

$\mathrm{Krn} \rightarrow$ le Krn,

Matajur $\rightarrow$ le Matajur,

Kolovrat $\rightarrow$ le Kolovrat,

Slivnica $\rightarrow$ le Slivnica,

Nanos $\rightarrow$ le Nanos,

Ratitovec $\rightarrow$ le Ratitovec,

Lajnar $\rightarrow$ le Lajnar,

Možic $\rightarrow$ le Možic,

Slatnik $\rightarrow$ le Slatnik,

vendar:

Uršlja gora $\rightarrow$ le Uršlja gora,

Škrbina $\rightarrow$ le Škrbina,

Soriška planina $\rightarrow$ le Soriška Planina,

Slemenova špica $\rightarrow$ le Slemenova špica, in:

Škarje $\rightarrow$ le Škarje,

Ciprnik $\rightarrow$ les Ciprnik.

Drug pogosti način prevajanja je, da pred lastno ime dodamo pojasnjevalno občnoimensko sestavino »le mont « ali »la montagne«:

Stol $\rightarrow$ le mont Stol,

Snežnik $\rightarrow$ le mont Snežnik,

Triglav $\rightarrow$ le mont Triglav,

Vogar $\rightarrow$ la montagne Vogar,

Hebat $\rightarrow$ la montagne Hebat,

planina Krstenica $\rightarrow$ la montagne Krstenica,

Pršivec $\rightarrow$ la montagne Pršivec,

planina Voje $\rightarrow$ la montagne Voje,

planina Blato $\rightarrow$ la montagne Blato,

Planina pri Jezeru $\rightarrow$ la montagne pri Jezeru,

Zgornji prevod ocenjujemo kot neuspešen oz. nedokončan prevod. Za potrebe jasnosti bi predlagali zapis z navednicami: la montagne "pri Jezeru«, za večjo zvestobo izvirniku pa: la montagne »Planina pri Jezeru«. Navedimo še nekaj primerov:

Kepa $\rightarrow$ le sommet Kepa,

Tojzlov vrh $\rightarrow$ le sommet Tojzlov vrh,

Vogel $\rightarrow$ le sommet Vogel,

Rombon $\rightarrow$ la montagne Rombon, 
Kaština $\rightarrow$ la montagne Kaština, planina Leskovca $\rightarrow$ la montagne Leskovca, planina Kuhinja $\rightarrow$ la montagne Kuhinja, Batognica $\rightarrow$ la montagne de Batognica.

Po analogiji z drugimi prevodi bi bilo bolj logično poimenovanje »la montagne Batognica

Podobno bi naslednja poimenovanja: »les sommets de Raduha, Ojstrica, Korošica; »les montagnes de Javornik et Lipanc« (planina »Lipanc« ne obstaja, obstaja pa »Lipanca«); la montagne de Lipanca et de Debela Peč« lahko poenostavili tako, da bi izpustili predlog »de«.

Občnoimensko sestavino imena lahko prevedemo, pridevnik na »-ska« pa slovenimo s strukturo »de+ime kraja«:

Ptujska gora $\rightarrow$ la montagne de Ptuj (Ptujska gora), toda:

Sveta Gora/gora nad Solkanom $\rightarrow$ (l'église sur) Sveta Gora nad Solkanom.

Prevajalec se tu ni odločil za slovenjenje občnoimenske sestavine, prav tako se ni odločil za eksplicitacijo, prevod ali navedek v oklepaju. Bralec bi verjetno o pomenu imena lahko sklepal na podlagi predloga »sur « in zunajjezikovnega znanja ali izkušenj, da so cerkve pač postavljene na vzpetinah. Prevod bi verjetno postal jasnejši z dodatkom občnoimenske sestavine: »sur le mont Sveta Gora nad Solkanom «.

\section{Imena kotlin, dolin, ravnin, jam, ipd. \\ a) Imena dolin}

Pri imenih dolin slovenimo občnoimensko sestavino, ki jo zapišemo z malo začetnico, pridevnik na »-ska/-ske« pa slovenimo s predložno zvezo »de« in zemljepisnim imenom:

Ljubljanska/ljubljanska kotlina $\rightarrow$ la vallée de Ljubljana,

Celjska/celjska kotlina $\rightarrow$ la vallée de Celje,

Krška kotlina $\rightarrow$ le bassin de Krško,

Idrijska/idrijska kotlina $\rightarrow$ la vallée d'Idrija,

Goriška ravnina $\rightarrow$ la plaine de Gorica,

Dolina Trente $\rightarrow$ la vallée de Trenta, la vallée de la Trenta,

kjer tujca navedemo na misel, da teče po dolini Trente reka Trenta, kot v naslednjih primerih:

la vallée de la Rečica, la vallée de la Soča.

Če z zgornjimi izrazi primerjamo naslednjega: »la vallée de la Savinjska dolina«, bi pomislili, da je »Savinjska dolina« ime reke, ki teče v Savinjski dolini. Jasnejše poimenovanje bi se torej glasilo »la vallée Savinjska dolina«.

Lahko se odločimo za dodajanje občnoimenske sestavine in ohranimo izvirno poimenovanje:

Panonska dolina $\rightarrow$ la plaine pannonienne (kjer prevod izgubi status lastnega imena),

Mislinjska dolina $\rightarrow$ la vallée de Mislinjska dolina,

Mežiška dolina $\rightarrow$ la vallée de Mežiška dolina. 
Verjetno bi bil v zadnjem primeru prevod jasnejši, če bi zapisali »la vallée de la Mislinja«, saj gre za dolino, ki je verjetno dobila svoje ime po istoimenski reki, ali: »la vallée de Mislinja«, kjer Mislinja pomeni ime občine, kjer se nahaja Mislinjska dolina. $\mathrm{Ob}$ imenu »la vallée de Mislinjska dolina « bi bralec verjetno sklepal, da je ime Mislinjska dolina ime kraja/naselja, ki bi ga lahko našel na zemljevidu, ne pa ime geografske enote.

Bržkone ni potrebno posebej pojasniti, zakaj naslednja prevoda ocenjujemo kot ne najbolj posrečena: »la vallée de Mislinje« - kraja ali naravnega pojava s tem imenom v Sloveniji ni; ter »la vallée de Logarska« - dolina Logarska?

\section{b) Imena jam}

Imena jam slovenimo tako, da prevedemo občnoimensko sestavino imena, pridevnik na »-ska/-ske« pa slovenimo s predložno zvezo »de« in zemljepisnim imenom:

Postojnska jama $\rightarrow$ la grotte de Postojna, les grottes de Postojna

Škocjanske jame $\rightarrow$ les grottes de Škocjan, les cavernes de Škocjan, des Škocjanske jame (primerjaj z imeni vrhov: »le Śkarje«),

Glija jama $\rightarrow$ la grotte de Glije. (Kozjansko, op. a.)

Zadlaška jama $\rightarrow$ la grotte Zadlaška (grotte de Dante) jama, jama Pekel $\rightarrow$ la grotte Pekel.

$\mathrm{V}$ spodnjih primerih opazimo različna prevajalska postopka:

jama Pekel $\rightarrow$ la grotte Pekel (Enfer),

kjer je prevajalec slovenil občnoimensko sestavino imena in ohranil izvirno ime, ki ga je v pojasnilo prevedel v oklepaju, ter:

Snežna jama $\rightarrow$ la grotte Snežna jama, Snežna jama sur (le mont) Raduha, kjer je prevajalec čutil, da mora pojasniti lego Snežne jame z dodajanjem besedne zveze »sur (le mont) Raduha«, kjer je pojasnjevalno občnoimensko sestavino dodal tudi pred imenom gore.

\section{ZAKLJUČEK}

Z žalostjo ugotavljamo, da je v analiziranih besedilih opaziti mačehovski odnos do lastnega geografskega leksikalnega izročila, zato bi veljalo razmisliti, komu zaupati avtorstvo slovenskih besedil. Če besedil, ki opisujejo pokrajino Slovenije in njene značilnosti, ne napiše geograf (ki bo preveril ustreznost uporabljenih poimenovanj $\mathrm{v}$ atlasu, na zemljevidu ali v drugih ustreznih virih), potem naj bo to avtor, ki bo premogel dovolj samokritičnosti, da bo preveril ustreznost poimenovanj.

Skupini osebnih in stvarnih imen sta $\mathrm{v}$ analiziranih besedilih pričakovano manj obsežni in $v$ glavnem $v$ prevodih ne zaznamo večjih zagat. Prevajalci večinoma uporabljajo prenos imen, zlasti to velja za osebna imena. Pri verskih imenih navajajo ustreznice v ciljnem jeziku. Zelo obsežna je skupina zemljepisnih imen. Medtem ko so enoimenska poimenovanja dokaj neproblematična, se več zagat pojavi pri večbesednih poimenovanjih. V glavnem opazimo delne prevode, kjer prevajalci prevedejo občnoimensko sestavino imena, lastnoimensko sestavino pa 
prenesejo. $\mathrm{V}$ nasprotju s pričakovanji se $\mathrm{v}$ besedilih pojavi relativno malo pojasnjevalnih opomb. $Z$ vidika informativnosti in jasnosti bi pričakovali natančnejše prevode tipa »la grotte Pekel (Enfer)《, »le roi Matjaž (Mathias)《 ali »Snežna jama sur (le mont) Raduha«. Okrcali bi delne prevode tipa »Jean Krstnik«.

Ker imajo analizirana besedila nezanemarljivo vlogo pri obveščanju in širjenju kulture, bi spodbudili k oblikovanju podrobnejših navodil oz. smernic za prevajanje lastnih imen $v$ tuje jezike, $v$ našem primeru $v$ francoščino. Ne delamo si utvar, da je mogoč le en prevod, ali da obstaja idealni prevod. Zaradi narave analiziranih besedil v svojih predlogih težimo le $\mathrm{k}$ jasnemu poimenovanju in, če se le da, tudi k zvestemu ohranjanju izvirnega poimenovanja.

\section{LITERATURA}

KLINAR, Stanko (1994) Slovenska zemljepisna imena v angleških besedilih. Radovljica: Didakta.

MAUGER, Gaston (1968) Grammaire pratique du français d'aujourd'bui. Paris: Librairie Hachette.

NEWMARK, Peter (1988) A Textbook of Translation. London: Prentice Hall.

NEWMARK, Peter (2000) Učbenik prevajanja. Ljubljana: Krtina.

SAZU, (1994) Slovenski pravopis 1 pravila. Ljubljana: DZS.

TOPORIŠIČ, Jože (1976) Slovenska slovnica. Maribor: Založba Obzorja.

\section{KORPUS}

PETAN, Zarko (2006) Le Procès du Loup. Paris: Editions Magnard, Classiques et contemporains, adaptation de Pierre Roudy.

STO (2005) Association des villes historiques de Slovénie. Ljubljana: STO.

STO (2008) Tentation naturelle. Ljubljana: STO.

STO (2010) La randonnée pédestre en Slovénie. Ljubljana: STO.

Vlada Republike Slovenije, Pisarna za odnose z javnostjo in mediji (2001) Faits sur la Slovénie. Ljubljana: Vlada Republike Slovenije, Pisarna za odnose z javnostjo in mediji.

Vlada Republike Slovenije, Pisarna za odnose z javnostjo in mediji (2006) Faits sur la Slovénie. Ljubljana: Vlada Republike Slovenije, Pisarna za odnose z javnostjo in mediji. 
POVZETEK

\section{Slovenska imena bitij in zemljepisna imena $v$ turističnih vodnikih in virih informativne narave, prevedenih $\mathrm{v}$ francoščino}

V prispevku smo z lastnoimenskega stališča analizirali francoske prevode slovenskih turističnih brošur, ki sta jih izdali Slovenska turistična organizacija ali Vlada Republike Slovenije, Pisarna za odnose $\mathrm{z}$ javnostjo in mediji.

Posvetili smo se imenom bitij (skupina je pričakovano manj obsežna) in zlasti zemljepisnim imenom. Medtem ko pri prevajanju imen bitij nismo zaznali večjih zagat, ne moremo trditi enako za zemljepisna imena. Podobno kot imena bitij tudi enobesedna zemljepisna poimenovanja ne povzročajo večjih zagat. Te se pojavljajo pri večbesednih zemljepisnih poimenovanjih.

Ker gre pri turističnih brošurah za pomemben vidik predstavitve države navzven, bi pričakovali, da bodo dobili prevajalci podrobnejše smernice za prevajanje lastnih imen. Upamo, da v pričujočem prispevku na dovolj jasen način osvetlimo prevajalske zagate in s tem koga spodbudimo k nastanku omenjenih smernic oziroma priporočil.

Ključne besede: lastna imena, prevajanje, analiza, turistične brošure, francoščina

\section{ABSTRACT}

\section{Slovenian proper names designing living beings and geographical proper names, in tourist brochures and informative booklets translated into French}

The article analyses French translations of Slovenian proper names in tourist brochures and booklets published by the Slovenian Tourist Board and the Government of the Republic of Slovenia, Public Relations and Promotion Office.

We analysed the names of living beings (the group of names was expected to be less numerous) and above all geographical proper names. While we did not notice any bigger problems when translating proper names of living beings, the same can be said for oneword geographical proper names. The opposite holds true for multi-word geographical proper names.

As we believe that tourist brochures play an important role in representing the country abroad, we would expect translators be given more detailed guidelines as far as translation of proper names is concerned. We hope that the present article brings forth the hard nuts of translating proper names in a manner to encourage the creation of such guidelines.

Key words: proper names, translation, analysis, tourist brochures and booklets, French language 